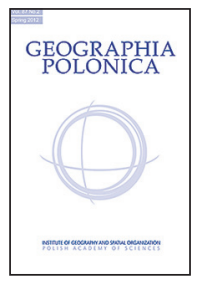 \\ INSTITUTE OF GEOGRAPHY AND SPATIAL ORGANIZATION \\ POLISH ACADEMY OF SCIENCES \\ www.igipz.pan.pl \\ www.geographiapolonica.pl
}

\title{
FUTURE GEOGRAPHY GRADUATES - HOW MUCH THEIR DEGREE MATTERS? STUDENT EXPECTATIONS AT COMENIUS UNIVERSITY, BRATISLAVA, SLOVAKIA
}

\author{
Eva Polonyová ${ }^{1}$ Marcel Horňák ${ }^{1}$ - Ivan Zelko² - Alexander Lux ${ }^{2,3}$ • \\ Thomas L. Rost ${ }^{4}$ \\ ${ }^{1}$ Department of Human Geography and Demography \\ Comenius University \\ Mlynská dolina llkovičova 6, 84538 Bratislava: Slovakia \\ e-mails: eva.polonyova@gmail.com, hornak@fns.uniba.sk \\ ${ }^{2}$ Institute of Chemistry \\ Slovak Academy of Science \\ Dúbravská cesta 9, 84538 Bratislava: Slovakia \\ e-mail: chemzelk@savba.sk \\ ${ }^{3}$ Department of Plant Physiology \\ Comenius University \\ Mlynská dolina Ilkovičova 6, 84538 Bratislava: Slovakia \\ e-mail: lux@fns.uniba.sk \\ ${ }^{4}$ Department of Plant Biology \\ University of California \\ One Shields Avenue Davis, CA 95616 Davis: USA
}

\begin{abstract}
Higher education has been perceived as a value, necessary for the process of societal development, as well as the development of individuals in post-socialist Europe. In this context, the paper aims to focus on Geography students and graduates to analyse their expectations for their futures in the discipline. Geography students are discussed here at Comenius University, Bratislava, Slovakia, but implications can be applied broadly. In particular, gender-based differences were revealed in Geography students' ambitions related to their future careers. Not surprisingly, attitudes of students and Geography teaching staff differ substantially in some aspects, including labour-market orientation of Geography curriculum. Lack of practical and business-related skills in existing curriculum might be a limitation of the graduates' labour prospects.
\end{abstract}

\section{Key words}

higher education $\bullet$ university $\bullet$ geography $\bullet$ professional carrier $\bullet$ expectations 


\section{Introduction}

The value of a university education is being questioned in the USA and other countries as the cost of that education increases. Hundreds of websites (e.g. http://www.huffingtonpost.com/tag/value-of-college-education) and blogs and published studies point out many sides of this issue (Higgins 2012; Immerwahr \& Foleno 2000; Kandiko \& Mawer 2013; Sanders et al. 2000), but the overwhelming conclusion seems to be that university graduates typically earn considerable more money over their lifetimes than those who do not make that education investment. In his online article, "The Great Debate: Is College Still Worth it?", Azziz (2014) argues that college graduates earn more, and are also less likely to lose their jobs during times of economic distress and have an easier time finding employment than those without a college education, even if only for two years. The current arguments about the value of higher education however tend not to include a discussion of the intangible aspects of Higher Education (HE) - such as learning to be a critical consumer of concepts and ideas, and the application of critical thinking and problem solving to everyday life.

There had not been many studies, acknowledging the importance of studying the university graduates in Slovakia, or other countries. Bukovská \& Plavčan (2007) have addressed the issue of a graduate's profile suitable for the knowledge-based economy and society. Elements that tend to be missing are universitybased career-guidance and support centers. Among the Slovak universities, however, this service is only now in its very initial phase (Markovič 2011). The delivery of career-advisory and guidance at post-communist-era universities is complex and challenging. The idea was only recently introduced in Slovak legal framework in 2009 (Act No. 317/2009 on Pedagogical Employees and Scientific Employees). The main goal of this paper was to map the key employability-related aspects of graduates and investigate the expectations of the students of Geography at Comenius University in Bratislava, Slovakia and to question the extent to which these expectations match reality. This investigation was carried out as a small-scale pilot case study, targeted to reveal at least some of the respondents' attitudes and views of $\mathrm{HE}$ and its role in the process of preparation for the labour market. To gain a wider perspective a parallel survey was conducted with Biology students (Rost et al. 2015). Hopefully, this report can contribute to planning for additions to the curriculum that can lead to a more successful labour market entry after the graduation.

\section{Comenius University, Bratislava, Slovakia: basis and background}

The capital region of Bratislava (NUTS2) includes 8 districts and counts over 602,430 inhabitants (SODB 2011). The city of Bratislava itself is the largest in the Slovak Republic. As Goddard \& Vallance (2013) discusses, the metropolitan areas of the country, benefit from the well trained human capital produced by a locally present university. According to surveys of the Ministry of Education, Science, Research and Sport of the Slovak Republic, Comenius University (CU) in Bratislava has always had a high credibility and popularity with students, being the largest (in number of students, reaching over 20,000 in 2013) and most traditional university in Slovakia. Out of the total number of university students in the country, about 15\% attend Comenius University in Bratislava (Lauko et al. 2011). Among its 13 faculties, the Faculty of Natural Sciences (FNS) is also ranking high, within the top 5 . Of the faculties at Slovak universities, the FNS stands out as one of the most attractive, ranking in top 7 Slovak Faculties.

The successfulness of the FNS graduates in the labour market has not been monitored. However, based on several sources (Tab. 1), graduates of Geography from Comenius University perform quite well in comparison with some other Natural Sciences graduates. To some extent, this may result from the location of $\mathrm{CU}$ in the capital city generating a wide spectrum of labour opportunities where 
Future geography graduates - How much their degree matters? Student expectations...

Table 1. Unemployment rate of Comenius University Natural Sciences graduates

\begin{tabular}{|c|c|c|c|c|c|c|}
\hline \multirow{3}{*}{$\begin{array}{l}\text { Study major } \\
\text { at Comenius } \\
\text { University }\end{array}$} & \multicolumn{6}{|c|}{ Year of graduation } \\
\hline & \multicolumn{3}{|c|}{$2005 / 2006$} & \multicolumn{3}{|c|}{$2008 / 2009$} \\
\hline & $\begin{array}{l}\text { number } \\
\text { of gradu- } \\
\text { ates }\end{array}$ & $\begin{array}{l}\text { unemployed } \\
\text { graduates }\end{array}$ & $\begin{array}{l}\text { unemploy- } \\
\text { ment rate } \\
\text { (by Sept. } \\
\text { 2006) }\end{array}$ & $\begin{array}{l}\text { number } \\
\text { of gradu- } \\
\text { ates }\end{array}$ & $\begin{array}{l}\text { unemployed } \\
\text { graduates }\end{array}$ & $\begin{array}{l}\text { unemploy- } \\
\text { ment rate } \\
\text { (by Sept. } \\
\text { 2009) }\end{array}$ \\
\hline $\begin{array}{l}\text { Natural Sciences } \\
\text { (all together) }\end{array}$ & 2886 & 230 & 8.0 & 2013 & 99 & 4.9 \\
\hline Mathematic \& Physics & 488 & 39 & 8.0 & 595 & 20 & 3.4 \\
\hline Geology & 240 & 7 & 2.7 & 200 & 7 & 3.5 \\
\hline Geography & 345 & 14 & 4.1 & 359 & 24 & 6.7 \\
\hline Chemistry & 431 & 27 & 6.3 & 150 & 6 & 4.0 \\
\hline Biology & 749 & 82 & 10.9 & 530 & 25 & 4.7 \\
\hline Environmental Sciences & 633 & 61 & 9.7 & 179 & 17 & 9.5 \\
\hline
\end{tabular}

Source: 2005/2006: Zvalová et al. 2007, 2008/2009: http://ekonomika.sme.sk/c/6111018/stat-zverejnilporadie-vysokych-skol-podla-uplatnenia-absolventov.html_Tabul'ka NEZAM odbory poradie_autorom = Minedu.sk.

Geography students often find part-time jobs during their student days and therefore have better chances to find permanent jobs after graduation.

\section{Students and graduates of geography in natural sciences}

Little research attention has focused on the employability of Slovak-university graduates (Zvalová et al. 2007 or Lesáková et al. 2012). Thus, only very little has been learned about the factors influencing graduates' position on the labour market, or the practical measures that could lead to its enhancement.

According to Lesáková et al. (2012), graduates in Natural Sciences perceived themselves as lacking practical experience, lacking foreign languages, stating only average communication skills; on the other hand they feel confident in computer skills and the soft skills and inter-personal relations and abilities.

When discussing the position of Geography students and graduates, we must mention the study of Kneale (2014) who clearly defines two obvious components of a university degree in Geography. The first of them covers knowledge; the second are the skills that the graduates acquire in the process of their study. However, as Kneale notes, geography knowledge, practices and skills are only one part of a Geography graduate's personality helping them to analyze and interpret geographical information, use geographical information system (GIS) or other analytical tools. However, there are many more personal, intellectual and practical attributes and skills expected by their future employers. If the graduates are not being equipped fittingly and connected practically enough, they can experience difficulties in their early career development (see Barrie 2006; Wolf 2007; Bridgstock 2009). Employability of Geography graduates leans not only on their subject-specific education but also on their other skills and competences, as indicated by Gedye et al. (2004), Marada \& Řezníčková (2005), Baylina \& Villanueva (2011) or Piróg (2014).

The issue of young unemployed geographers within a similar environment of transitive Europe has been discussed by Piróg (2011, 2012, 2014). Piróg (2011) reported that graduates ranked highly, concerning their skillset self-assessment and self-efficacy of young 
geography students. Moreover, she points to the changes recently made in the curricula that are more focused on practical experiencebased skills. She mentions real cooperation between employers and the university, when speaking of newly designed teaching standards (Piróg 2012). The truth, however, is that a number of geography graduates are clearly facing real difficulties, when aspiring for a 'geography related' position. Moreover, increasing numbers of graduates are not able to find any job at all. In fact, only the teachers, GIS specialists and land use planners are the exception (Piróg 2014).

In the context of the above discussion on geography graduates' employability, one should not forget to mention a so-called 'reputational capital' (a profile of the university), as one of the key factors (Brown \& Hesketh 2004), especially within post-socialist European societies such as those found in Slovakia.

Being aware of the relevant employability skills and appropriate training of young geographers within the curricula should, according to Arrowsmith et al. (2011), be a crucial activity. Besides the list of geographical knowledge gained, authors point to what turns a geographer into an employable graduate and they emphasize the importance of the external work-related learning, as well as the presence and contribution of the employers throughout the process of the curriculum creation.

Similarly, Hennemann \& Liefner (2010) reported and emphasized the importance of mandatory 3 to 4 month internships, as a powerful tool to introduce the real workrelated environment to the students. Still, the Geography graduates find themselves lacking experience and express the need of connecting more closely to their future job (labour market) during their studies - the authors push towards curricula improvement. Numerous studies (Gabris \& Mitchell 1989; Andrews \& Higson 2008; Lowden et al. 2011) directly emphasize that real-work based learning (experience in practice) has the crucial impact on the alumni employability success and thus it should be the very crucial element, compounding the curricula. So in right balance with the expert knowledge, this 'experiential' learning, or a kind of 'practical intelligence' development is obviously a key to success (Gibb et al. 2013: 13). Practice attained on internships and placements has a high potential to awaken personal abilities and promote mutual understanding or active future collaboration. Its promotion should be happening through the supportive work of advising / career services, embedded into the practice and structure of departments / faculties. The above mentioned inspired us to include the aspect of practical skills into our empirical survey commented below in this paper. As shown below, the issue of poor links between Geography education and real labour market demands is one of the key flaws of Geography curriculum at Comenius University, and by extension, other universities as well.

\section{Pilot case study of the geography program at CU Bratislava}

\section{Methodology}

Applying a questionnaire method, Geography students' and teaching staff members' expectations for a university education in geography were questioned. The data collected in this way have lead us towards a reflection on the existing curriculum in Geography and the actual process of meeting the real needs of the market. The analysis itself was built on a questionnaire-based data collection, distributed to 229 students, at the end of the spring term of 2012. The total number of respondents included 4 different groups of $\mathrm{Ge}$ ography students:

1. students of the first and second years of BS study (various specializations of $\mathrm{Ge}$ ography Curriculum, including the Students of Teacher-education of Geography, 165 students in total);

2. students of the first year of MS (students of Human Geography, 25 students);

3. 39 students of external study of Human Geography (various years);

4. 41 Geography teaching staff members.

These questionnaires included the same set of questions, with only minor and relevant 
formulation changes, which enabled us to gain a mirror image to students' responses.

The final database consists of 140 female students and 89 male students surveyed. Interestingly, this gender aspect has shown a number of remarkable variations, concerning the individuals' perspective that determined their answers. The structure of the survey enabled us to also filter through various other groups, however, due to the sample volume the possibilities of such filtering were limited. Only gender-related differences were analysed in this study. In some questions only one response was expected, but for several questions we allowed more than one option. In these cases, the overall frequency of individual options was considered. Out of the questionnaire, answers to the following questions were analysed:

- "What is the most important reason for you to attend university?"

- "What is the most important reason to go to get a university degree?"

- "Why did you select Comenius University?"

- "What is your probable occupation when you graduate?"

- "Which of these teaching methods do you consider most important?"

As for the sample size, the total number of responding students (reaching over 200) can be considered as sufficient. Similar surveys were carried out in Germany (Hennemann \& Liefner 2010) or the UK (Gedye et al. 2004), both leaning on over 200 respondents' responses. In our case, the number of respondents covered a considerable part of Geography students attending Comenius University in the respective academic year.

\section{Results and discussion of the case study}

Looking at the reasons why students decide to attend university in geography shows interesting results, although some of the responses may not be very surprising. Figure 1 indicates for students (both male and female) that getting a good job and making money are substantial motivations. However, we should mention that up to $20 \%$ of both male and female students chose option "to learn interesting things" which somehow corresponds with findings of experts dealing with perception of geography and reporting that geography (as a subject) is very much related to travel experience, "learning about the way people live everywhere, [...] understanding of different issues (mainly environmental) in the world" (Hopwood 2004: 353). Teaching staff showed a rather critical view, based on their personal subjective perception of students' ambitions. Nearly one third of Geography teaching staff think that students attend the university "to obtain a university diploma" which is perceived as a formal necessity opening gates to high-end labour opportunities and a highquality life (Fig. 1).

Figure 2 brings a more general view on $\mathrm{HE}$, its value and benefits for an individual in the society, but the options related to good professional positions and expectations of high incomes seem to be dominant again. Nearly $28 \%$ of male students and $33 \%$ of female students expect that a university degree will allow them to get a good job. Over $20 \%$ of both male and female respondents hope to hold decision-making positions. Job outlooks of university graduates are generally better compared to non-graduates (see also e. g. Arrowsmith et al. 2011 or Baylina \& Villanueva 2011). Female students focus a little more on the expectation of getting a good professional position (one third of responses from female students), which might be a reflection of their negative perception of women's status in postsocialist societies and labour markets (Rochovská 2004). Having practical experience with the labour market, Geography staff members think that it is not only about better jobs. One third of their responses included also gaining "skills to solve problems" as an important benefit of a university education for a graduate.

Geography students' ambitions may reflect different attitudes to their future professional career. Labour markets in all transitive societies have undergone substantial changes within the last two decades. As noted by Piróg (2014), geography graduates in Poland have usually high flexibility and employability. 
However, their chances to find a job related to the subject of their study (Geography) have been decreasing. Although no such study has been published in Slovakia, we can assume that employability of Comenius University graduates of Geography will be high, based on the data from Zvalová et al. (2007). Students of geography feel that Comenius University has a good reputation and education programs (Fig. 3). Female students are considerably more sensitive to this point - $40 \%$ of them declare that a good reputation of Comenius University was the main factor of their decision, while this was important only for $30 \%$ of male students. Compared to attitudes of Geography students at the University of Plymouth in England (Gedye et al. 2004), attractiveness of module contents is not decisive for Comenius University undergraduates (about 20\% on average in our sample, while over $50 \%$ University of Plymouth undergraduates declared that content of module subjects had been the key factor of their decision). On the other hand, Geography teaching

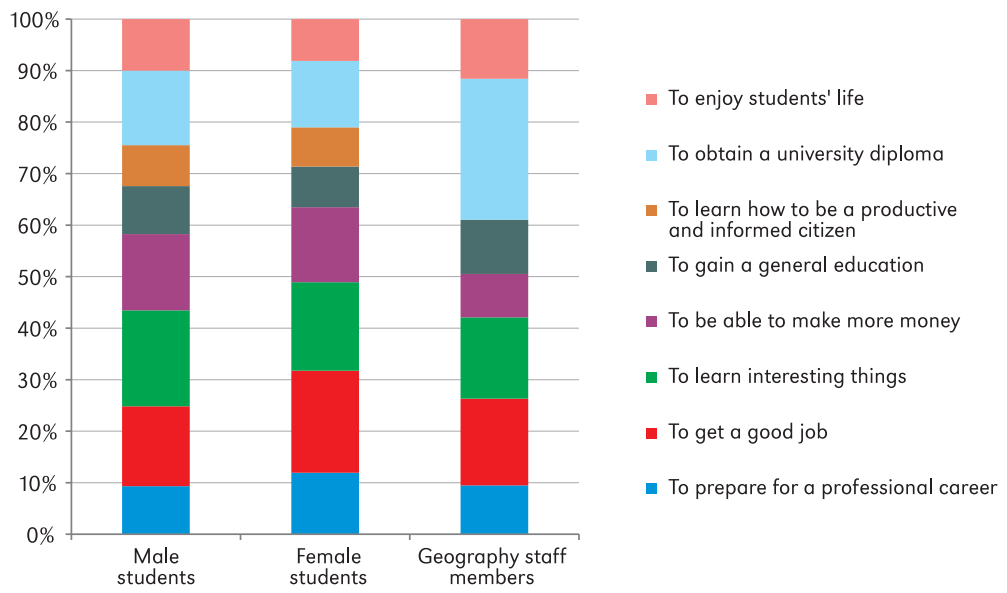

Figure 1. The most important reasons to attend a university - structure of responses of Geography students and teaching staff members

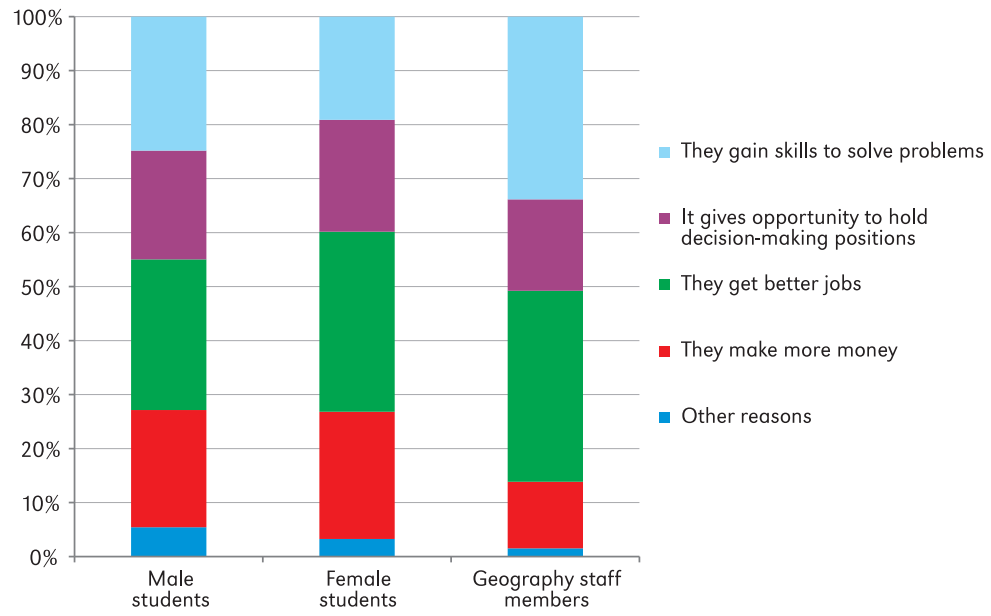

Figure 2. Advantages and value of university degrees for the graduates - structure of responses of Geography students and teaching staff members 
staff members at Comenius University stand on a rather more rational position, responding that it is predominantly employment opportunities that should be attractive and decisive for Comenius University graduates.

Based on personal perception of the authors of this study, most of the external students as well as part of the daily students have had some experience with either part-time or full-time jobs. In many cases, students of final year of Masters' study indicate that they have already gained promising professional positions where they intend to stay on after graduation.

Figure 4 shows that opinions of future Geography graduates upon their prospective professional careers are rather realistic, respecting that the education system has limited opportunities for future geographers. Business career and entrepreneurship seem to be the dominant visions (52\% of male student respondents and nearly $43 \%$ of female students), although we should emphasize that this may cover occupations where knowledge

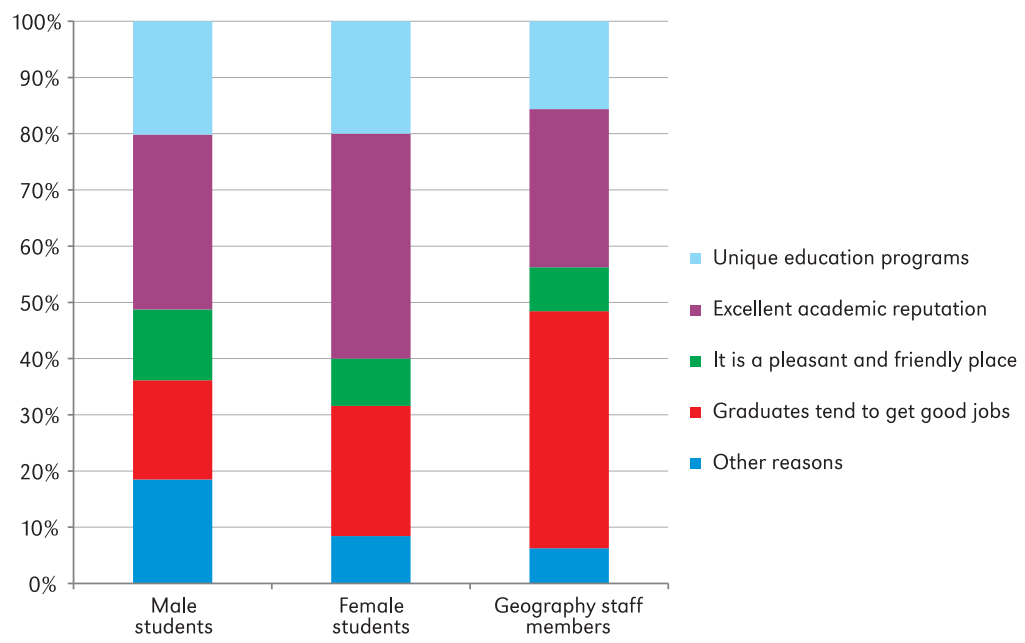

Figure 3. Reasons to select Comenius University in Bratislava - structure of responses of Geography students and teaching staff members

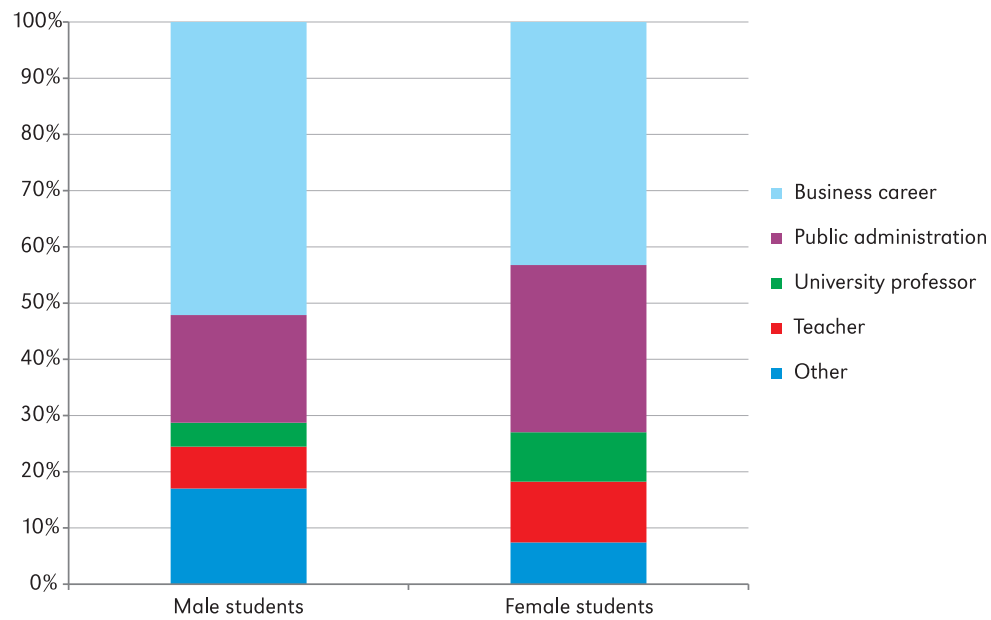

Figure 4. Most probable occupation of Geography students after graduating 
and skills related to their study might be utilized, such as urban- and regional-planning companies, market research departments of production companies, travel agencies, geodetic and cartographic companies, etc. We can observe a similarity with outcomes of Baylina \& Villanueva (2011), who, however, presented a wider range of opportunities for Geography graduates (such as geo-marketing, environmental education, and geopolitics. However, we feel that the recent Geography curricula at the Faculty of Natural Sciences, Comenius University in Bratislava do not reflect students' ambitions to succeed in doing a business career properly; this is a big challenge for improvements of the whole Geography education. Not surprisingly, a considerable segment of the respondents (mostly female students) thought of positions in the public sector. This might include central, regional and local planning authorities, environmental agencies, and social development departments. Gedye et al. (2004) who carried out a survey on a sample of Geography graduates in British environment show even a wider range of Geography graduates' employment (including human resources, management, police or military service). We can find similar results in a study published by Piróg (2011) reporting on Polish Geography graduates. Findings of Marada \& Řezníčková (2005) who surveyed Charles University (Prague) geography graduates show that most of the graduates had found their jobs in education, state administration, science and research field, regional development and self-government. However, no such scientific survey has been done on Geography graduates in Slovakia.

The preference of a public sector training (as well as a profession of a teacher) by female students $30 \%$ of female students compared to less than $20 \%$ of male students) reflects the attitudes of women in post-socialist societies. Smith et al. (2008) point to a high proportion of women in office sector in post-socialist cities, which reflects general women's attempts to find secure positions in the labour market. Similarly, academic and teaching careers are preferred by female Geography students rather than by male ones $(20 \%$ and $12 \%$, respectively). These observations correspond to what Gedye et al (2004) revealed with the sample of Geography graduates from the University of Plymouth, where $16 \%$ of graduates were working as teaching staff.

Geography students tend to consider mainly practical exercises and field work courses as crucial. Over $62 \%$ of undergraduate respondents feel that exercises and field work are the key methods of their education. Although this does not necessarily point to lacking practical experience and skills

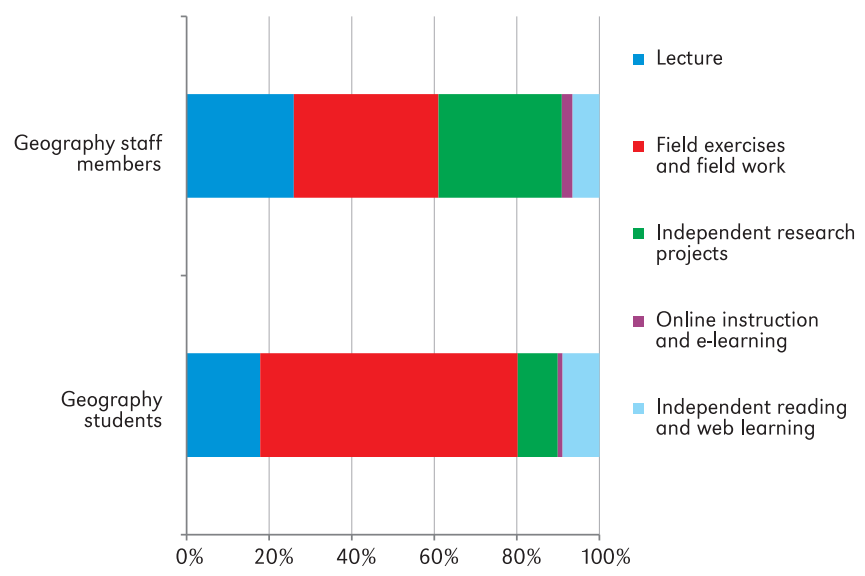

Figure 5. Which of teaching methods do Geography students and teaching staff members consider as the most important one? 
within current Geography curricula at Comenius University, we believe that this component of the curricula should be considered. A similar deficiency has been reported by Hennemann \& Liefner (2010) at one of German universities and by Gedye et al. (2004) referring to research realized at University of Plymouth. Not surprisingly, the view of Geography staff at Comenius University is slightly different, considering also lectures and working on individual research projects as very important (Fig. 5), while only $35 \%$ of the staff respondents think that exercises and field work should be the key element of Geography modules. This may suggest limits of current attitudes of the staff members and indicate necessary further improvements of the curricula towards a broader real-work based learning, which correspondents with findings and recommendations of Piróg (2012).

\section{Concluding remarks}

Our intention was to discuss the role of HE and its institutional background in the process of preparation of future Geography graduates for the labour market on the one hand, and analyze the expectations of the Geography students sample group at Comenius University in Bratislava, Slovakia on the other hand. Although our small-scale pilot case study does not reflect all aspects of the complex issue of Geography major at Comenius University, it still enables us to make some general conclusions and recommendations. These may be as following:

- Geography students at Comenius University in Bratislava generally understand the relevance of university education for their future professional careers, but a certain traditional aspiration to "learn more" seems to be still one of the dominant motivations. We can assume that this would be obvious for all Geography students whose studying is often rooted in deep personal interests.

- Attractiveness of HE stands on our sample students' assumptions that as university graduates they will have a better chance to succeed in the labour market, which is an important benefit in the post-socialist environment. It is evident that the Geography students perceive the University as an institution responsible for their future career and employability.

- Expectations on future professional careers of the sample group of Geography students reflect economic reality of the post-socialist society where business sector represents the dominant source of income and opportunities. We therefore assume that more focus on entrepreneurial and businessrelated skills could be placed in the curriculum. The second largest share of the sample group declared their hope to find their future jobs in the public sector. This finding corresponds well with the results of surveys focused on Geography graduates occupational placement in some other post-socialist societies.

- According to our expectations, some gender-related differences in students' expectations were revealed. Female Geography students tend to be more sensitive to reputation of the University, which may guarantee better jobs in their future professional career. Also, female respondents declared their willingness to work for the public sector (education system, public administration, etc.) rather than in business or management-related positions. On the other hand, male respondents perceive Geography as a matter of their personal interest, expecting to gain practical skills to solve various problems, and they also express interest in individual business careers.

- Discrepancies between Geography students' and teaching staff attitudes appear mainly in perceiving the motivations to study Geography at Comenius University. While students tend to express rather pragmatic reasons (such as getting good and well-paid jobs), teaching staff members generally feel that students' ambitions are limited to "obtaining a university diploma".

- Not surprisingly, substantially different are the attitudes of Geography students and Geography teaching staff members 
towards the role of practical skills teaching, where the viewpoint of the staff members seems to be rather conservative and insufficiently open to real-work based teaching methods. As our literature review clearly indicates, this dimension of $\mathrm{HE}$ seems to be crucial for graduates' future careers. However, an obvious lack of these elements is still present in Comenius University Geography curriculum. This limited understanding of the education-practice relationship as a priority may be a result of an incomplete process of the university system's adaptation in post-socialist societies. Therefore, we believe that real-work based teaching methods and internships allowing experiential learning should be more developed at Comenius University to become one of the substantial parts of Geography curricula.

Geography students understand the general purpose and benefits of gaining an academic degree and generally they tend to choose this field of study according to their natural interest. They and their parents understand the importance of finding a suitable position after graduation, and they trust the university to prepare with the skills to achieve their career goals. This is the theory, but the curricula for Geographers at the CU is still obviously missing a few basic, practical knowledge-awakening and training mechanisms

\section{References}

Abel J.R., Deitz R., 2012. Do colleges and universities increase their region's human capital? Journal of Economic Geography, vol. 12, no. 3, pp. 667-691.

Arrowsmith C., Bagoly-Simó P., Finchum A., Oda K., Pawson E., 2011. Student employability and its implications for geography curricula and learning practices. Journal of Geography in Higher Education, vol. 35, no. 3, pp 365-377.

AzzIz R., 2014. The Great Debate: Is College Still Worth It?, The Huffington Post. http:// www.huffingtonpost.com/dr-ricardo-azziz/ and their application. Geography education is still omitting business related knowledge and specific soft skills training, which are crucial for new graduates. The above stated critical conclusions are fully in accordance with similar studies on Geography students' and graduates' labour prospects surveyed at other Central-European universities (cited earlier in the paper).

We consider this paper to be an important starting point in order to evaluate the level, to which a university education could potentially be, and to which it actually is being beneficial for the graduates. Based on the findings presented in the paper, the key recommendations for the Geography curriculum architects at $\mathrm{CU}$ are to gain more support from the business as well as public sectors, leading to wider opportunities of co-operation through fellowships and practice-oriented teaching as an obligatory part of the Geography major.

\section{Acknowledgements}

This research was, in part, funded by a Fulbright Senior Specialist grant to T.L. Rost.

Editors' note:

Unless otherwise stated, the sources of tables and figures are the authors', on the basis of their own research. debate-college-worth_b_4561068.html [20 August 2015].

BARRIE S., 2006. Understanding what we mean by generic attributes of graduates. Higher Education, vol., 51, no. 2, pp. 215-241.

Baylina M., Villanueva M., 2011. Challenges, expectations and reality: The adaptation of a geography degree to the European Higher Education Area. European Journal of Geography, vol. 2, no. 1, pp. 29-45.

Bukovská A., PlavČan P., 2007. Príprava absolventa univerzity pre spoločenskú prax. Technology of Education, vol. 15, no. 8, pp. 2-5. 
BRIDGSTOCK R., 2009. The graduate attributes we've overlooked: Enhancing graduate employability through career management skills. Higher Education Research and Development vol. 28, no. 1, pp. 31-44.

BrockBANK A., McGıLL, I., 2007. Facilitating reflective learning in Higher Education. Maidenhead: McGraw-Hill International.

Brown P., Hesketh A.J., 2004. The mismanagement of talent: Employability and jobs in the knowledge-based economy. Oxford: Oxford University Press.

CLIFFORD V.A., 1999. The development of autonomous learners in a university setting. Higher Education Research \& Development, vol. 18, no. 1, pp. 115-128.

Davis B., 1993. Tools for Teaching. Chapter 60: Student Rating Forms. San Francisco, CA: JosseyBass Publishers.

Gabris G.T., Mitchell K., 1989. Exploring the relationships between intern job performance, quality of education experience, and career placement. Public Administration Quarterly, vol. 12, no. 4, pp. 484-504.

Gault J., Redington J., Schlager T., 2000. Undergraduate business internships and career success: Are they related? Journal of Marketing Education, vol. 22, no. 1, pp. 45-53.

Gedye S., Fender E., Chalkey B. 2004. Students' undergraduate expectations and post-graduation experiences of the value of a degree. Journal of Geography in Higher Education, vol. 28, no. 3, pp. 381-396.

GibB A., Haskins G., Robertson I., 2013. Leading the entrepreneurial university:Meeting the entrepreneurial development needs of higher education institutions. [in:] A. Altmann, B. Ebersberger (eds.), Universities in change: Managing higher education institutions in the age of globalization, Springer: New York, pp. 9-45.

Goddard J., Vallance P., 2013. The university and the city. Regional Studies Association. Routledge.

Hennemann S., Liefner I., 2010. Employability of German geography graduates: The mismatch between knowledge acquired and competences required. Journal of Geography in Higher Education, vol. 34, no. 2, pp. 215-230.

HIGGINS H., 2012. Why some graduates believe university was a waste of time. http://www. theguardian.com/higher-education-network/ blog/2012/may/01/graduates-university-employability-waste-time [8 February 2015].

Hopwood N., 2004. Pupils' conceptions of geography: Toward an improved understanding. International Research in Geographical and Environmental Education, vol. 13, no. 4, pp. 348-362.

IMMERWAHR J., Foleno T., 2000. Great Expectations: How the public and parents - white, African American and Hispanic view higher education. San Jose, CA: National Center for Public Policy and Higher Education.

KANDIKo C.B., MaWer M., 2013. Student Expectations and Perceptions of Higher Education: Executive summary. London: King's Learning Institute.

KNeale P.E., 2014. Study Skills for Geography Students: A Practical Guide. Abingdon: Routledge.

KNIGHT P.T., YORKE M., 2002. Employability through the curriculum. Tertiary Education and Management, vol. 8, no. 4, pp. 261-276.

Lauko V., GuRÑ́ÁK D., KrižAN F., TolmáčI L., 2011. Školstvo na Slovensku $v$ kontexte regionálnych disparít. Prešov: Vydavatel'svo Michala Vaška.

Lesáková D., Dzimko M., Farkašová V., 2012. Uplatnenie absolventov vysokých škôl na trhu práce. Vyhodnotenie výsledkov prieskumu, Projekt Lifelong Learning, SAAIC [The national agency for lifelong learning]. http://web.saaic. sk/llp/sk/doc/rozne/survey_employability.pdf [15 August 2016].

Lowden K., Hall S., Elliot D., LeWIn J., 2011. Employers' perceptions of the employability skills of new graduates. London: Edge Foundation.

Marada M., ŘezníčKovÁ D., 2005. Charles University Geography Graduates in Practice: The Relationship between the Concept of Education and Professional Success [in:] K. Donert, P. Charzyński (eds.), Changing Horizons in Geography Education. Toruń: Herodot Network, pp. 156-160.

MARKovič D., 2011. Kariérové poradenstvo na vysokej škole.Inovácie, plánovanie a kvalita sociálnych služieb v komunite, Zborniěk priěspevkov $z 1$. ročniěka medzinaěrodnej vedeckej konferencie, pp. 36-41.

OECD, 2010. How many secondary students go on to tertiary education? Highlights from Education at a Glance, OECD Publishing, http:// dx.doi.org/10.1787/eag_highlights-2010-5-en [15 August 2017].

PIRÓG D., 2011. Graduates of geographical studies on the labour market in the process 
of transformation in higher education. Prace i Studia Geograficzne, vol. 48, pp. 161-172.

PIRÓG D., 2012. Changes to the conception of Geography curricula within university education in Poland in the 21st century in the face of labour market challenges. European Journal of Geography, vol. 3, no. 2, pp. 24-41.

PIRÓG D., 2013. Selected theories of higher education graduates' transition into the labour market in a knowledge-based economy. Prace Komisji Geografii Przemysłu Polskiego Towarzystwa Geograficznego, vol. 23, pp. 146-159.

PIRÓG D., 2014. Destinations of geography graduates on the labour market in Poland and other countries. Geographia Polonica, vol. 87, no. 1, pp. 95-111.

RochovskÁ, A., 2004. Problems of poverty in Slovakia with focus on the most threatened groups of people [in:] M. Balej, M. Jeřábek (eds.), Geografický pohled na současné Česko, Acta Univesitatis Purkyninae č. 100. Ústí nad Labem: Univerzita Jana Evangelisty Purkyně, pp. 130-139.

Rost T.L., Polonyová E., Horñák M., Zelko I., LuX A., 2015. Student expectations for higher education in biology at Comenius University, Bratislava, Slovakia. International Journal of Biology Education, vol. 4, no. 2, pp. 63-77.
RubensteIn I.Z., 2006. Educational expectations: How they differ around the world: Implications for teaching es/ college students. Community College Journal of Research and Practice, vol. 30, no. 5-6, 433-441.

Sanders P., Stevenson K., King M., Coates D., 2000. University students' expectations of teaching. Studies in Higher Education, vol. 25, no. 3, pp. 309-323.

Smith A., Stenning A., Rochovská A., Swiatek D., 2008. The emergence of a working poor: Labour markets, neoliberalisation and diverse economies in post-socialist cities. Antipode, vol. 40, no. 2, pp. 283-311.

SODB, 2011. Sčitanie obyvatelov, domov a bytov 2011. Population Census 2011, https://census2011.statistics.sk/tabulky.html [17 October 2016].

Wolf A., 2007. Round and round the houses: The Leitch review of skills. Local Economy vol. 22, no. 2, pp. 111-117.

Zvalová M., Srnánková l., Hrušovská J., 2007. Uplatnenie absolventov vysokých škôl $v$ praxi. I. etapa. Zamestnatel'nost' a zamestnanost' absolventor vysokých škôl. Bratislava: Ústav informácií a prognóz školstva.
(C) Eva Polonyová - Marcel Horňák - Ivan Zelko •

Alexander Lux • Thomas L. Rost

(C) Geographia Polonica

(C) Institute of Geography and Spatial Organization

Polish Academy of Sciences • Warsaw • 2017
Article first received • March 2015 Article accepted • December 2016

\section{http://rcin.org.pl}

